\title{
Geo-Spatial Mapping of the Western Bushveld Rustenburg Layered Suite (Rls) in South Africa
}

\author{
O.A. Bamisaiye ${ }^{1}$ \\ ${ }^{1}$ Department of Geology, University of Pretoria, Private bag X20 Hatfield, Pretoria 0028, South Africa \\ Correspondence: O.A Bamisaiye, Department of Geology, University of Pretoria, Private bag X20 Hatfield, \\ Pretoria 0028, South Africa. E-mail: adunseyi@gmail.com
}

Received: September 22, 2015

Accepted: October 21, 2015

Online Published: November 26, 2015

doi:10.5539/jgg.v7n4p88

URL: http://dx.doi.org/10.5539/jgg.v7n4p88

\begin{abstract}
Trend surface analysis (TSA) was used to investigate the structure and thickness variation pattern and to resolve trend and residual component of the structure contours and isopach maps of the Rustenburg Layered Suite (RLS) across the Bushveld Igneous Complex (BIC). The TSA technique was also employed in extracting meter scale structures from the regional structural trends. This enables small-scale structures that could only be picked through field mapping to be observed and scrupulously investigated. Variation in the structure and thickness was used in timing the development of some of the delineated structural features. This has helped to unravel the progressive development of structures within the RLS. The results indicate that present day structures shows slight changes in both regional and local trends throughout the stratigraphic sequence from the base of the Main Zone to the top of the Achaean floor. Structures around the gap areas are also highlighted. This paper represents the third of a three-part article in Trend Surface analysis of the three major limbs of the Bushveld Igneous Complex (BIC). This first part focused on the Northern Bushveld Complex, while the second part focused on the Eastern Bushveld Limbs.
\end{abstract}

Keywords: Trend, Rustenburg Layered Suite (RLS), timing of structures, local and regional scale structures

\section{Introduction}

Mapping the subsurface of the world's largest layered intrusion (BIC) will not only enhance the understanding of underlying geology and structure, but will also assist in making better interpretations of some of the surface features that could not be adequately examined due to insufficient outcrops at the surface. However, subsurface data cannot be directly assessed except through boreholes, tunnels and geophysical survey.

Different geophysical data have been employed for regional study of the Bushveld Complex (Odgers, Hinds \& Von Gruenewaldt, 1993; Odgers \& Du Plessis, 1993). However, seismic reflection data seems to be more useful for local structural mapping and for mine-planning purposes (Campbell, 1994; 2006; 2009; 2011; Du Plessis, \& Levitt, 1987; Webb, Cawthorn, Nguuri \& James, 2004; Cawthorn \& Webb 2001), but needs to be complemented with other datasets for better interpretation (Chunett \& Rompel, 2004). High-resolution imaging capabilities of 2D and 3D seismic reflection surveys have been utilized for mapping underground structures in some parts of the Bushveld Complex, most of these studies are extremely localized. Another drawback in utilizing high-resolution seismic data for a regional study such as this is its availability, high cost and proprietary restriction, hence, the need to source for a more readily available data.

However, ample borehole data are available at the Council for Geoscience, Pretoria and were extensively utilized for this research. The data were directly logged from borehole cores and are considered more accurate than inferred data. The data used has a good spatial distribution over the entire study area. However, most of the available borehole log data were drilled for exploration purpose and as such only terminate within the economic layers or a little below, thus making it difficult to accurately represent the geometry beyond the available depth. Therefore, the focus of this study is limited to about $3000 \mathrm{~m}$ depth. Notwithstanding, the results accurately present conceptual 3D models of the study area that better define the geometric pattern of each stratigraphic interval, provide better understanding of subsurface geology, aid interpretation that serves as a basis for future exploration targets. These scattered (x,y) borehole data with detail lithostratigraphic information for each stratographic layer require interpolation to convert them to meaningful geological information. 
Trend surface analysis (TSA) is an interpolation technique for estimating the spatial distribution or trend from dispersed observation points by fitting a surface through a set of points (x, y, z) (Agterberg 1984; Unwin, 2009). This technique has been applied widely in geological exploration for recourses that are constrained by structure and stratigraphy (Krumbein, 1959; Merriam \& Harbaugh, 1964; Cook, 1969; Baird, 1971; Wren, 1973; Davis 1973; Wharton, 1993; Davis et al. 2002; Evenick, 2008; Mei, 2006).

The major objective is to analyse and describe the relationship between structural trends, residual structures (small-scale structures) and thickness of stratigraphic units with the aim of distinguishing between pre, syn and post emplacement structures. The study also attempts to find out the mechanisms responsible for localization and the geometry of structures as well as reconstruction of the developmental history of the RLS within the western lobe of the Bushveld Complex. The relationship between the structure in which magma accumulates and thickness of the deposit are usually inverse. This is because previously structurally negative areas i.e. lowland areas such as trough and basins before deposition will receive more influx than structurally positive area, except if the area has been structurally disturbed by later tectonic activities.

\subsection{Local Geology of Western Bushveld Complex}

The Bushveld Igneous Complex (BIC) rocks were emplaced just above the Transvaal sequence about 2060 Ma (Walraven, Armstrong \& Kruger, 1990). The BIC is situated in the northeastern part of South Africa (Figure 1). It consists of mafic to ultra-mafic rocks known as the RLS as well as acid rocks known as Lebowa Granites, which intrude and overlay the RLS together with Rashoop Granophyre (Barnes \& Maier 2002: South African Committee for Stratigraphy (SACS), 1980; Von Gruenewaldt et al., 1986). The RLS outcrops prominently as Western, Eastern and Northern, far northern, far western and lastly the southwestern limb that is covered by recent deposits (Kinnaird et al., 2005).

Repeated magma injection coupled with mineral precipitation and interaction with new magma addition is said to be responsible for the repetition of layers or cyclic units in the RLS (Cawthorn \& Walraven, 1998, Cawthorn et al., 2006). These formed sequence of layered rocks that are igneous in origin, but exhibit the characteristics of a sedimentary sequence. The RLS ranges in thickness from a few $\mathrm{cm}$ to more than $8000 \mathrm{~m}$ (Cawthorn and Web 2001; Manyeruke, 2003; Kinnaird, 2005). However, there is little relief on the upper surface of the RLS. The layered sequence consists of cycles of magma cumulates that consist of Upper zone, Main zone, Critical zone, the Lower zone and the Marginal zone. Figure 1 shows the geological map of the Western Bushveld Complex in South Africa. 


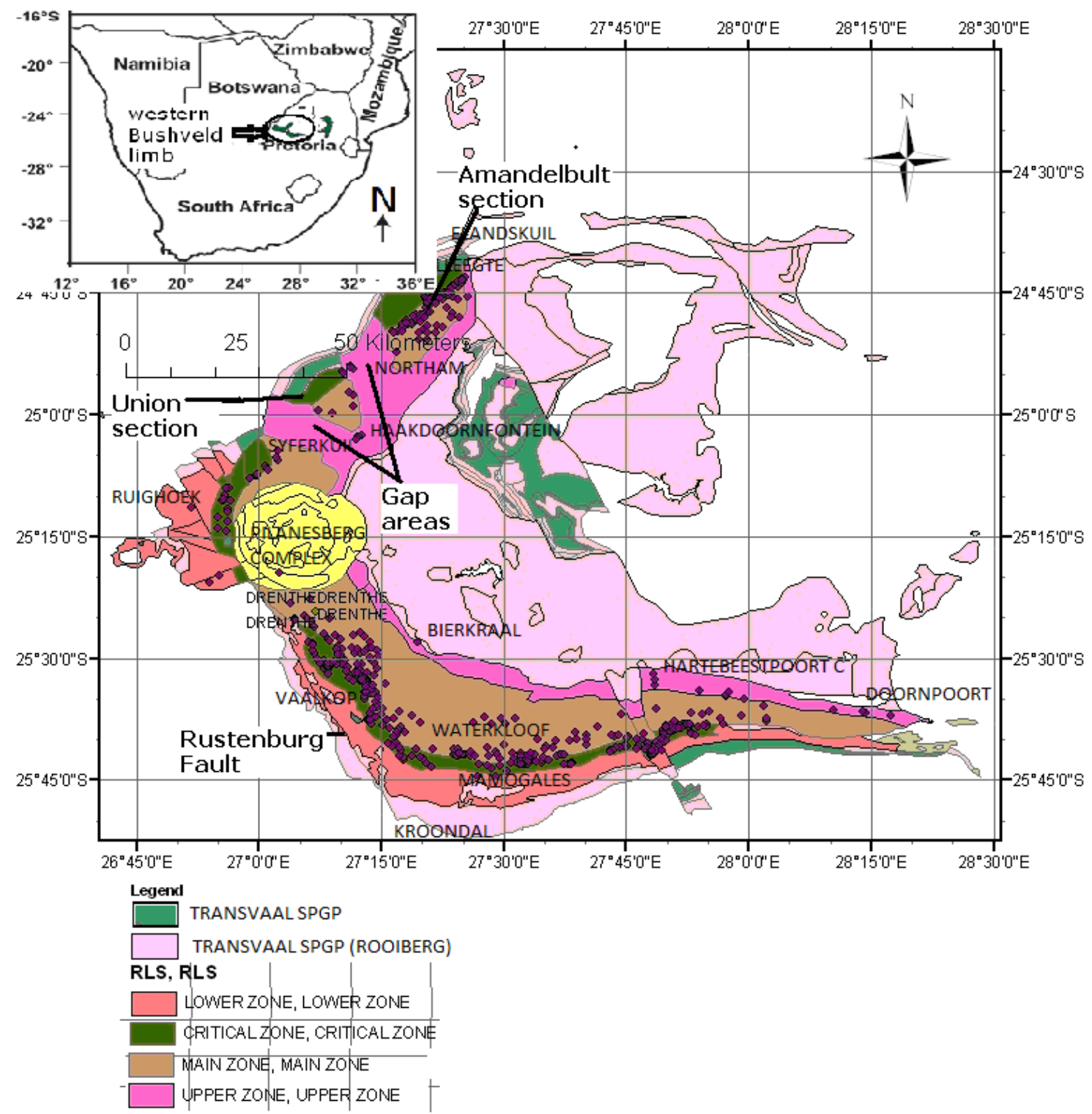

Figure 1. Geological map of the Western Bushveld Complex with some farm names

\section{Method}

This study analysed borehole log data on RockWorks $15^{\circledR}$ software platform to compute both the structure and isopach maps from the actual data. While the trend surfaces were generated for each stratigraphic units and subsequently grid maths algorithm was used to calculate the residual values and create residual map for each layer. These residual maps represent small-scale structures in the area. The identification and interpretation of the result was enhanced with available field and geophysical data. The residual report for each stratigraphic unit of the RLS from first through fourth order were produced and correlated. Higher orders (i.e fifth and sixth orders) were evaded due to edge effect errors, the analysis was limited to the fourth order. Trend surfaces residual maps were generated by subtracting trend surface data from input (actual) data. Fitness of the trend surface to input data was determined based on correlation with previous field and geophysical mapping results, and not entirely on the usual best fit test which only ascertain the reliability of the generated map (Agterberg, 1984; Mei, 2006). To exercise more geological control, available options such as high fidelity, declusting and power options were extensively utilized and results were adequately tested by first applying the different options on a test area with well-known geological and structural information before extending the analysis over the other parts of the study area. The conceptual model for the study is illustrated in Figure 2. 


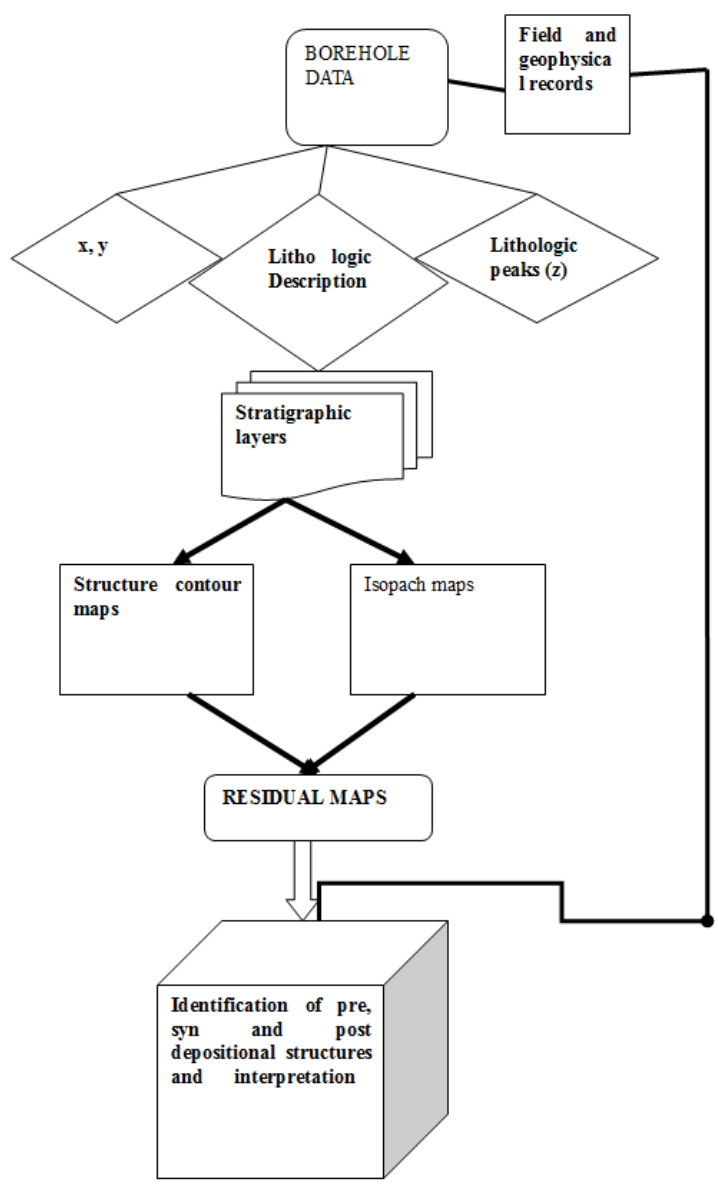

Figure 2. The conceptual model of study

\section{Trend Surface Analysis Results of Parts of the Rustenburg Layered Suite (Western Bushveld Limb)}

For the purpose of this discussion, the RLS rocks in the western Bushveld limb are divided into three sections; the northwestern part, the central part and the southwestern part. The Upper and Main Zone lithology are more abundant and forms the core of our discussion.

\subsection{The Northwestern Bushveld Upper Zone And Main Zone Residual Structure And Isopach}

The Upper Zone structure residual maps show a general decrease in gradient from the SW to the NE. The structure contours are more regular in the southwestern side (west of the Union section), than in the northeastern. The NE part of the Union section shows gradual decrease in gradient compared to the southwestern side but the structure is more complicated. First to fourth order Upper Zone residual structure maps and structural trend in the Northwestern Bushveld Complex are shown in Figure 3. Main Zone base residual structure shows a major NE decrease in gradient. The NE extreme exhibits a sharp slope to the southeast from the NW and SW. The southern part is marked by wide structural high while the northern part has a depression that extends to the NW (Figure 5). Isolated structural high exists around the Kamelehoek farm at the centre. The structure of Amandelbult section shows a structural low domain in the south and structural high in the northern parts as indicated in Figure 4. This central section is also marked by irregular or rapidly undulating structural surface compared to the southwestern side.

The residual isopach map of the Upper Zone in the southwestern Bushveld Complex shows a prominent NW-SE thickening trend as indicated in Figure 4. However, at the centre i.e. around Union section there is an isolated thickening, which thins out to the NE and SW. This abrupt decrease in thickness trend in the NE coincides with the northern gap area while the other corresponds with the southern gap area. The isolated thickening also thins out abruptly to the NW on Spitskop farm and later thickens further northwards on Kameelhoek farm.

On the first order Main Zone isopach residual map in Figure 6, the structural high areas correspond to areas with thinning while the negative residual domain areas (structural low) correlate with areas with thick deposition. 
Both the trend and residual structure match up with the structural grain. Abrupt thickening around the Amandelbult section marks the southeastern parts of the maps.
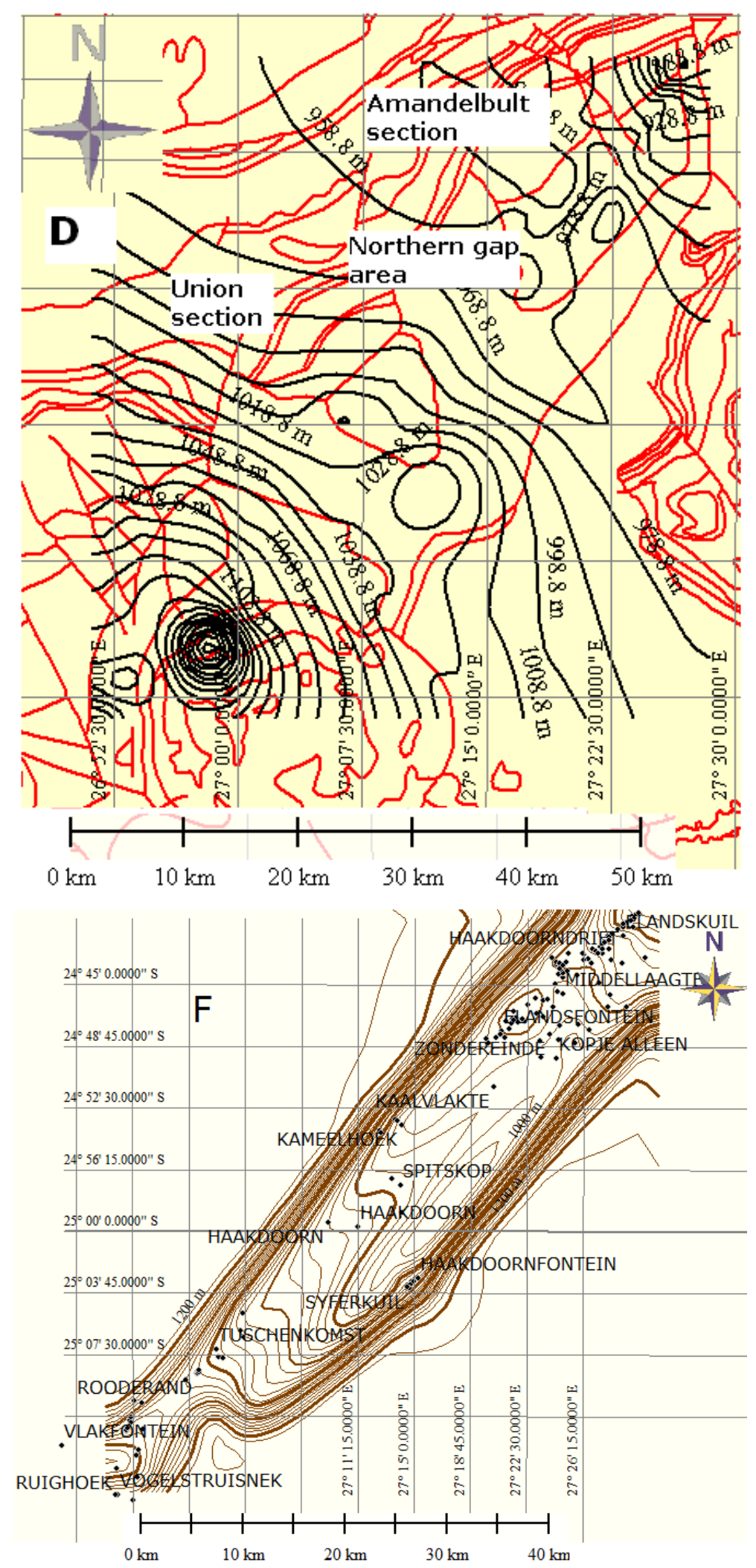

Figure 3. The residual structural map of the Upper Zone (D) showing the contours lines (black) with the geological outline indicated with red lines (F) shows the regional structural trend of Northwestern Bushveld Complex (contour interval 10) 

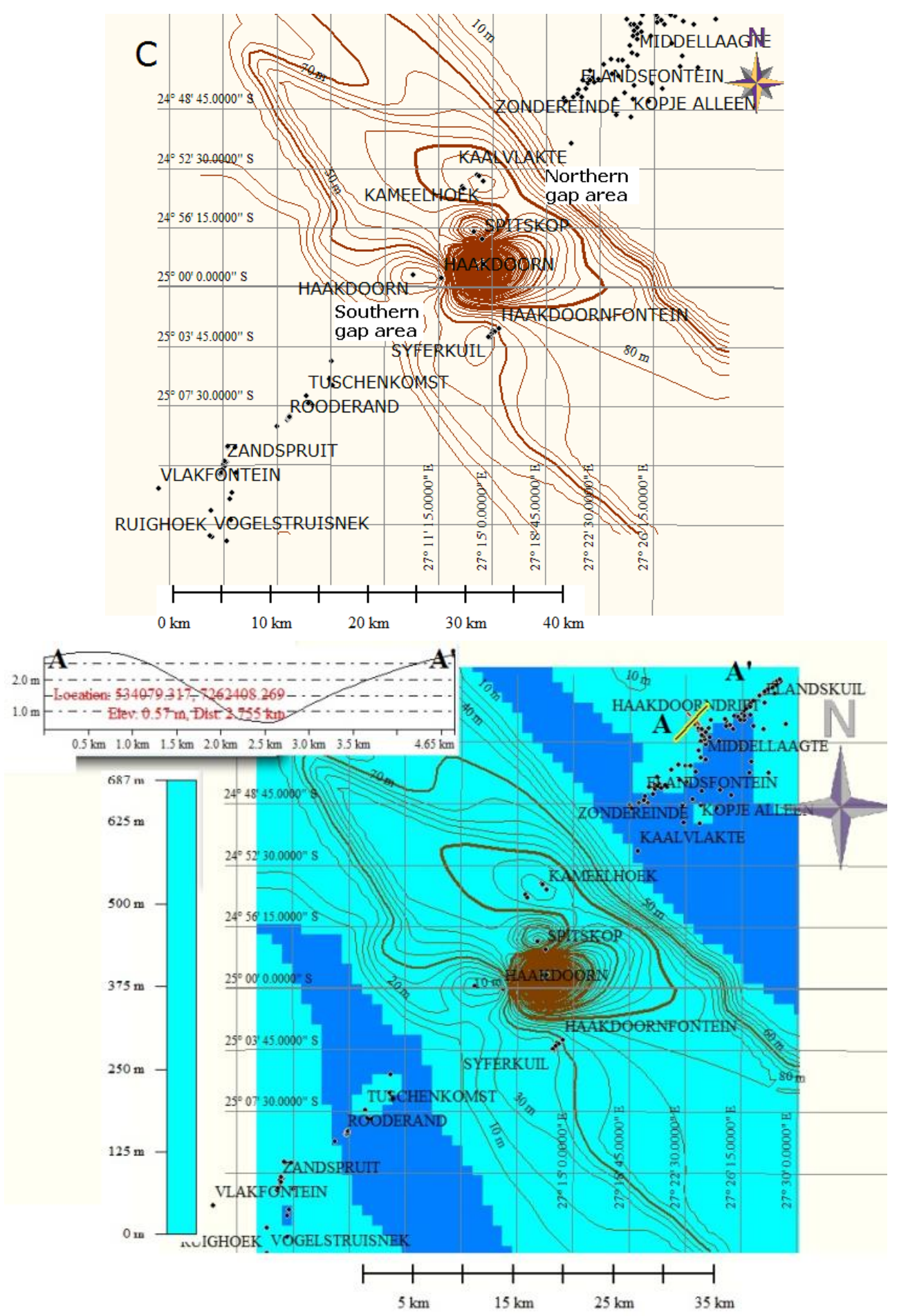

Figure 4. The residual isopach for the Upper Zone of the Northwestern Bushveld Complex (contour interval is 10) 


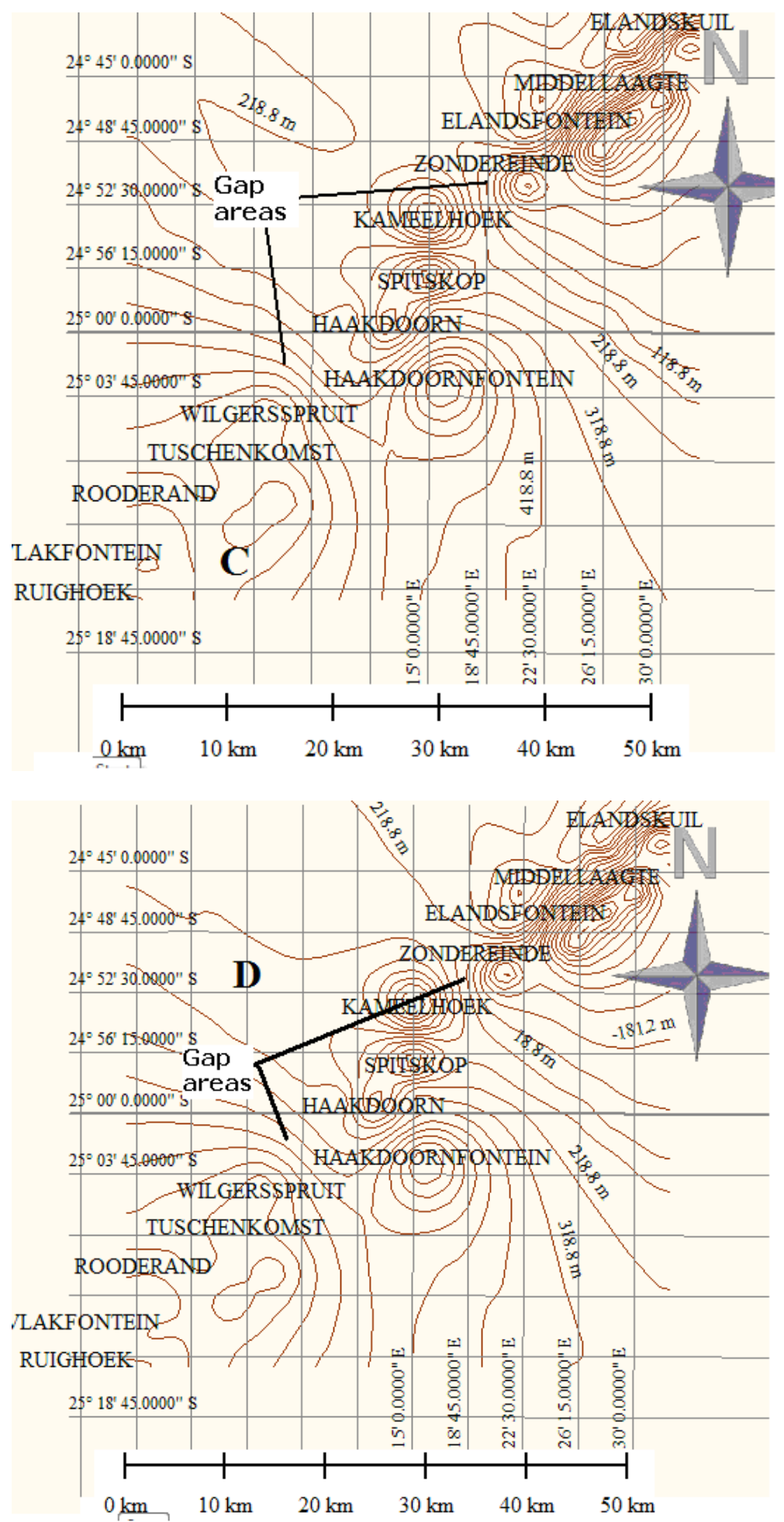

Figure 5. Main Zone interval residual structure contour maps for third (C) and forth order (D) respectively 

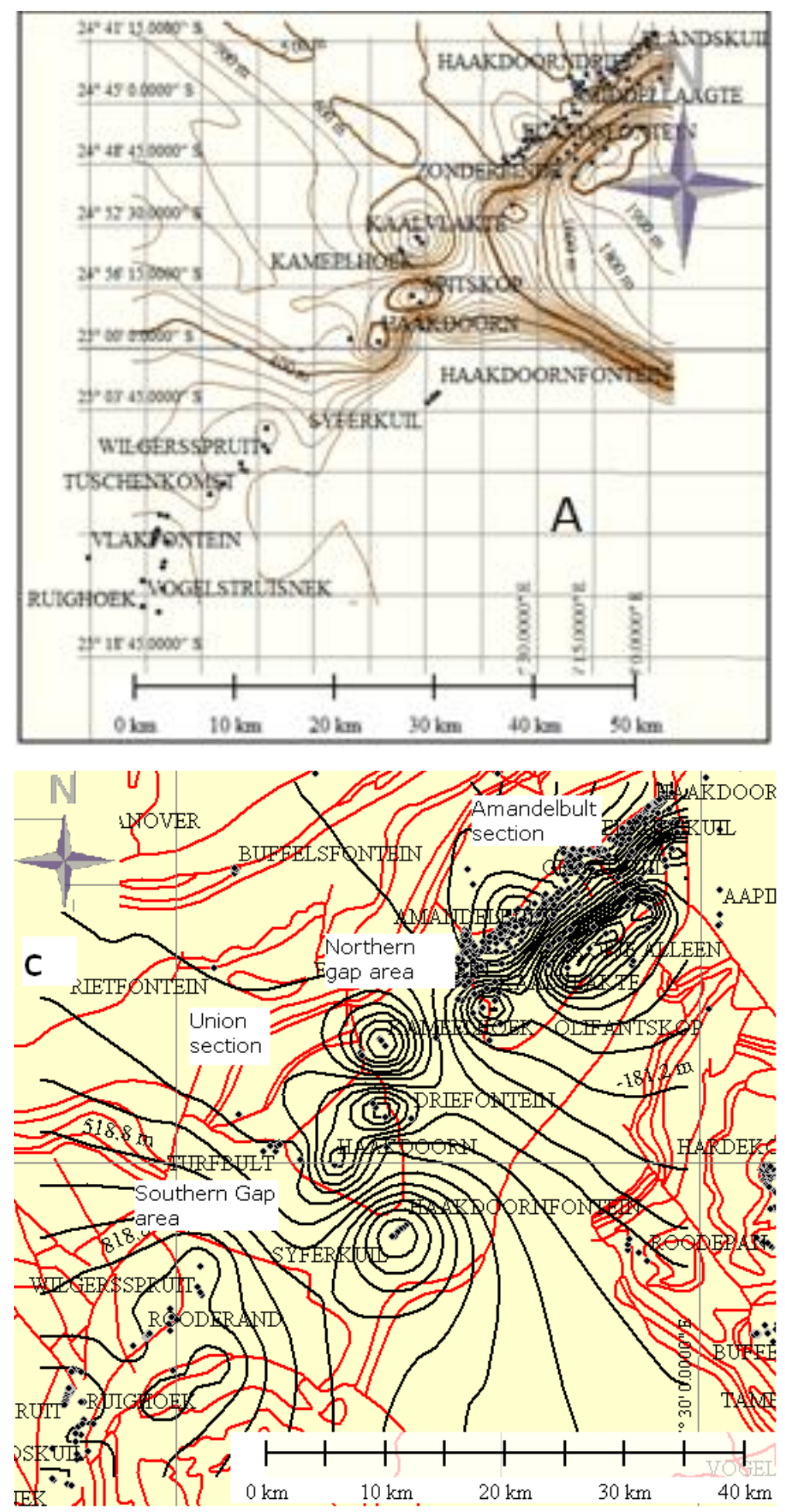

Figure 6. First and fourth order (A and C) Main Zone residual isopach maps of NW Bushveld Complex

\subsection{The Northwestern Bushveld Structure and Thickness Relationship}

Strong abrupt thinning on both sides of the central section of the Upper Zone residual isopach map corresponds with the gap areas. Using the residual isopach in Figure 4 for illustration, the central part of the northwestern Bushveld on the Upper Zone residual isopach maps show a centrally located NW thickening trend with abrupt thinning to the east and west. However, on the Main Zone residual structure and isopach map (Figure 5 and 6 ) the same central portion is marked by a NW thickening trend in the north and southeast thickening trend in the 
south. The NW to NNW dominant structural trend in this area is admitted to have strong control on most of the prominent faults such as the Rustenburg Fault (Bumby et al., 1998), the Brits and Welgevonden faults (Du Plessis \& Walraven, 1990).
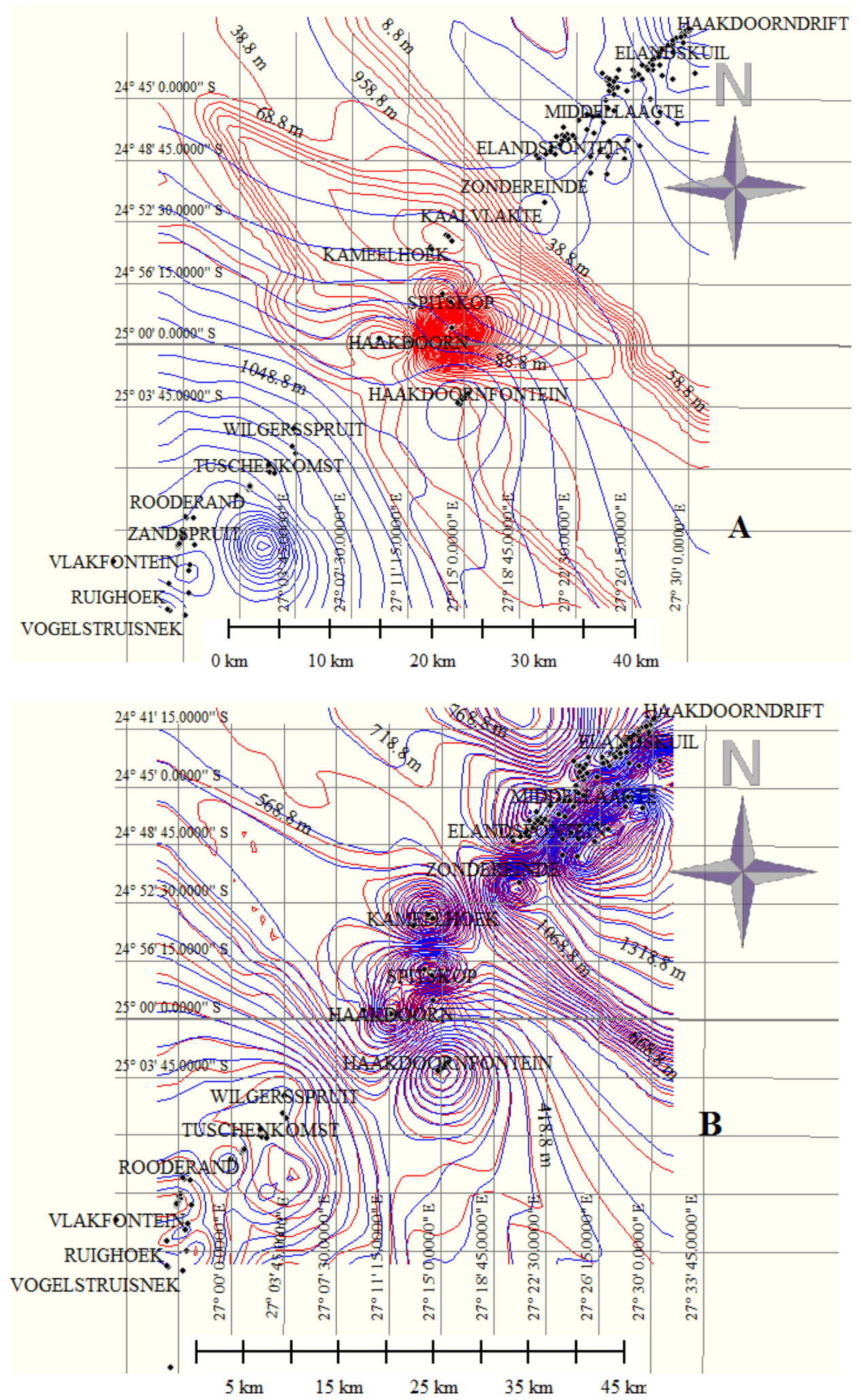

Figure 7. (A) Upper Zone structure contours (blue lines) and isopach isolines (red lines) and (B) shows the relation between Main Zone structure (blue lines) and isopach (red lines) 
Figure 7A indicates the independent relation between Upper Zone residual isopach and structure while Figure 7B reveals a strong inverse correlation between the Main Zone residual isopach and structure. Strong southeast thickening coincides with a structural negative or a structural low area of the Amandelbult section, the thickness is maximal in the axial portion of this structure. This area is marked by structure controlled down-dip accumulation of RLS rocks

\subsection{Residual Structure of Central Parts of the Western Bushveld Complex}

Upper Zone residual structure in the central part of the Western Bushveld Complex, revealing a strong NW- SE positive structure to the immediate south of the Pilanesberg Complex. The western parts of the Pilanesberg Complex also exhibit abrupt changes in structure pattern around Ruighoek farm.

A structural negative domain probably controlled by presence of faults dominate the area occupied by the Upper Zone around the Pilanesberg Complex. The Main Zone residual isopach surfaces for first to fourth order are marked by wide positive structure domain with NE trend around the northern parts of the Pilanesberg Complex. The southern parts show a predominant eastward thinning from the centre with a steep slope to the west and a general NNW-SSE trend. Two small, isolated structural negative domains that are separated by a structural positive domain occur around the Schaapkraal farm at the northern part of Rooikoppies farm in the southwestern Bushveld Complex.

The Upper Zone residual isopach maps indicate positive thickening towards the central part of the map and especially at Bierkraal farm. It also reveals a sudden increase in thickness between Kroondal and Mamogales in the southern parts. This area coincides with a negative structural domain on the residual structure map.

The Main Zone structure of the northern Pilanesberg Complex trends mostly NE while the trend in the southern parts of the Complex is NNW-SSE, parallel to the trend of Rustenburg Fault (Figure 9A). A positive structural domain dominates the western part of the fault and a negative domain is prominent in the eastern part i.e. towards the centre.

\subsection{Relationship Between Structure and Isopach of Central Parts of the Western Bushveld Complex}

The Upper Zone of this section did not show intervse relation between structure and isopach (see Figure 8, 9 and 10). However, the Main Zone to Lower Zone structure contour interval show strong correlation in structure and thickness, especially around the Rustenburg Fault (see Figure 11) where the trend is predominantly NW- SE to NNW-SSE indicating NW-SE structural grain control on the RLS rocks.

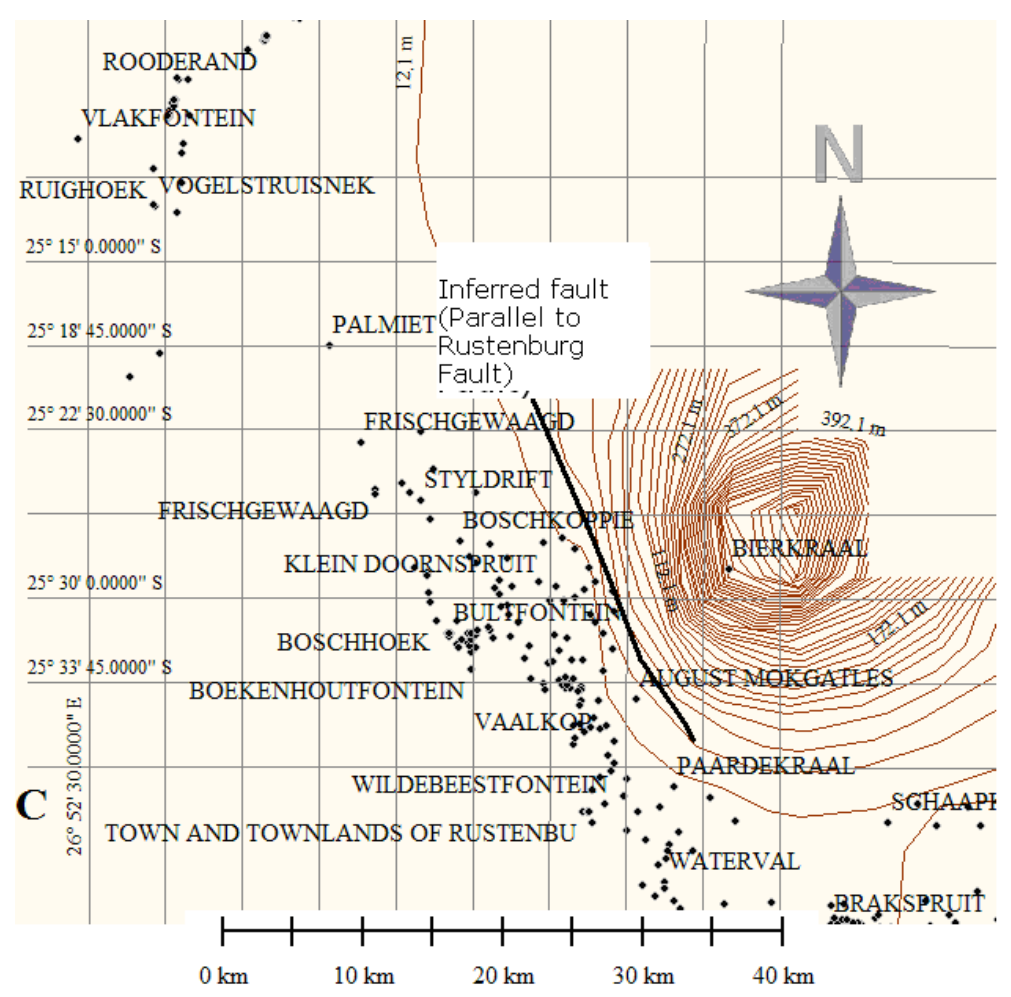




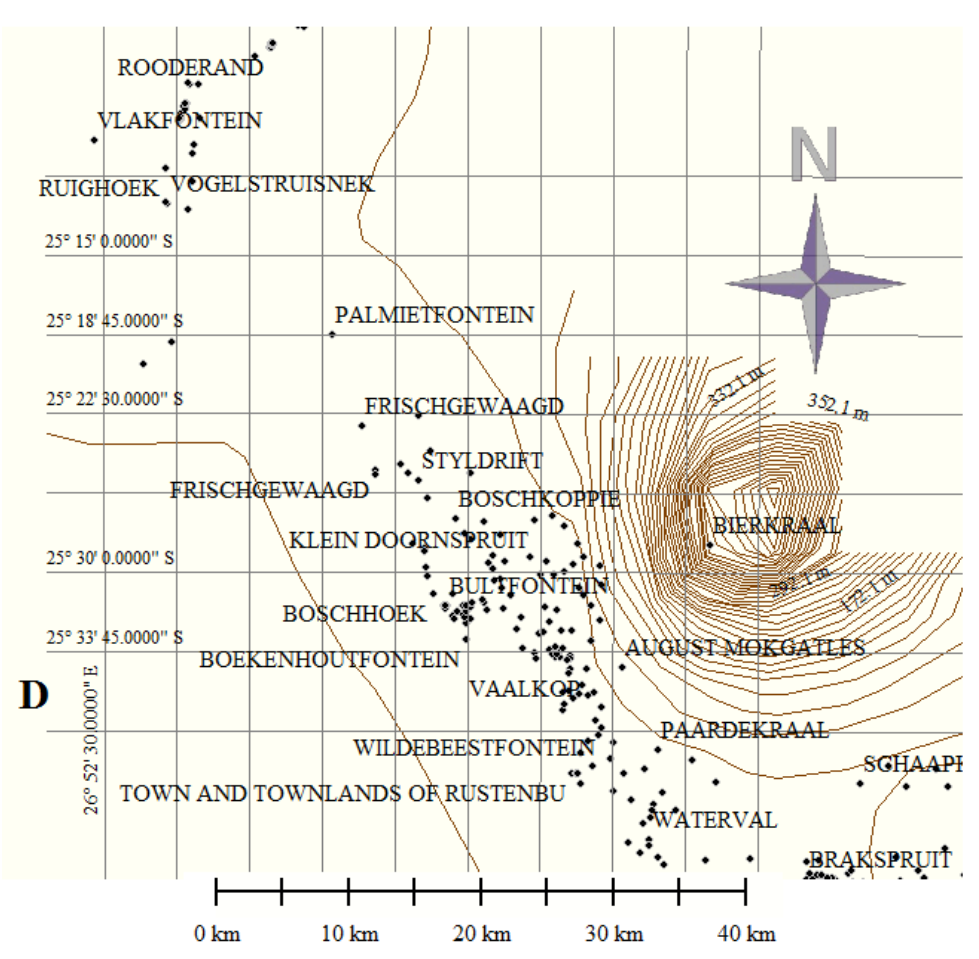

Figure 8A. Third and fourth order Upper Zone residual structure of central parts of the Western Bushveld Complex (contour interval 50)

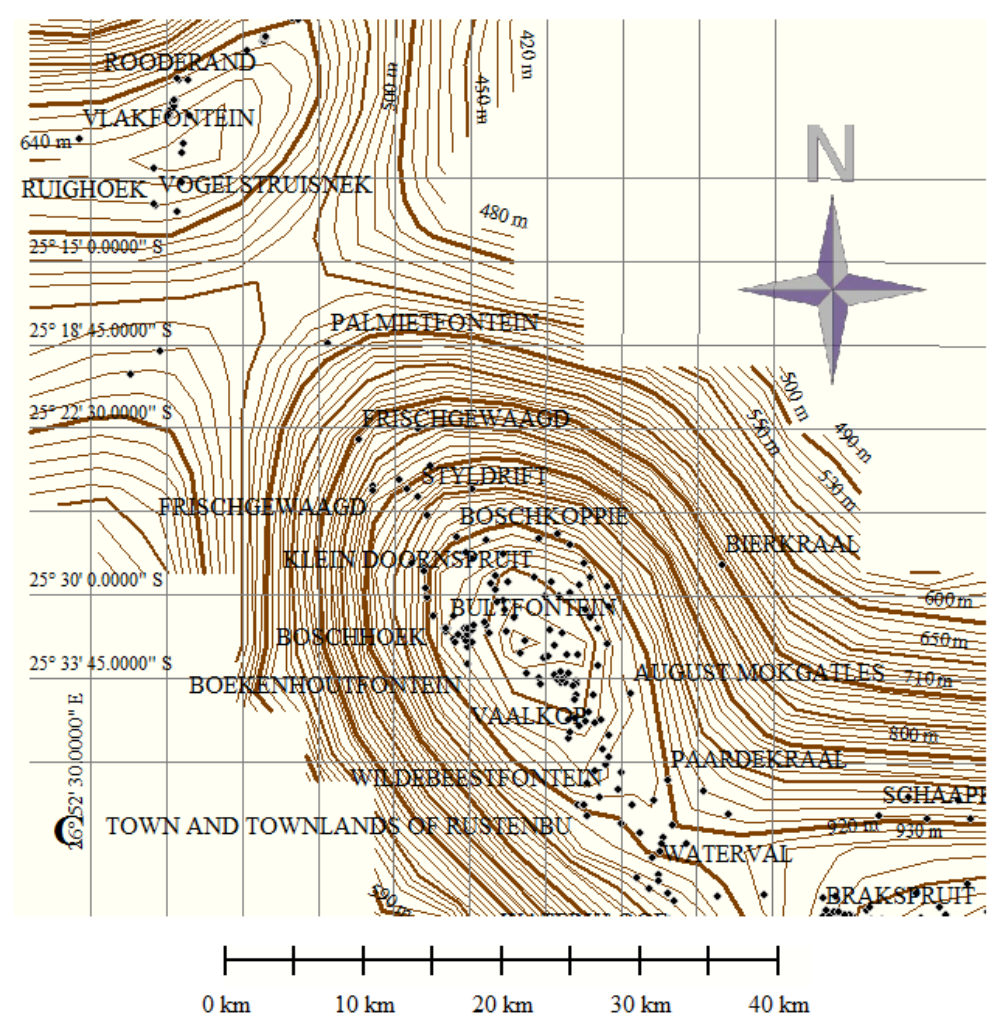




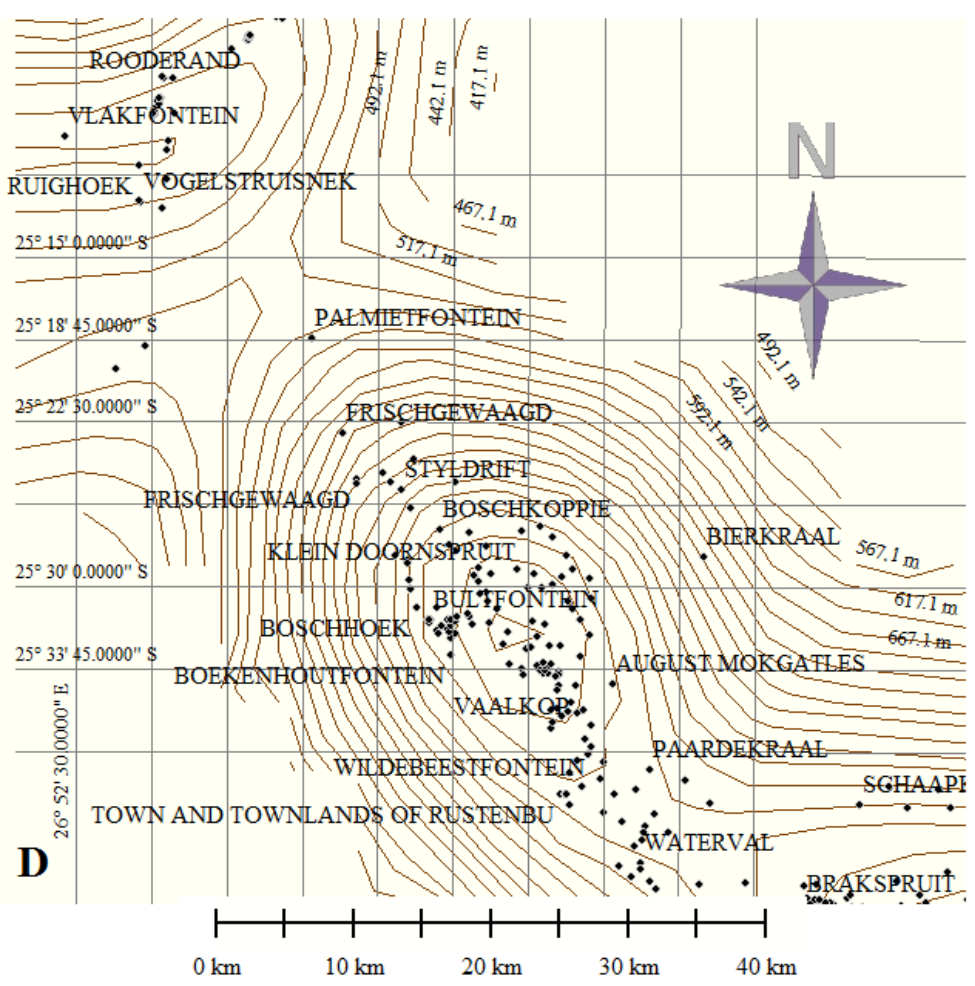

Figure 8B. Third and fourth order Upper Zone residual isopach of central parts of the Western Bushveld Complex (contour interval 50)

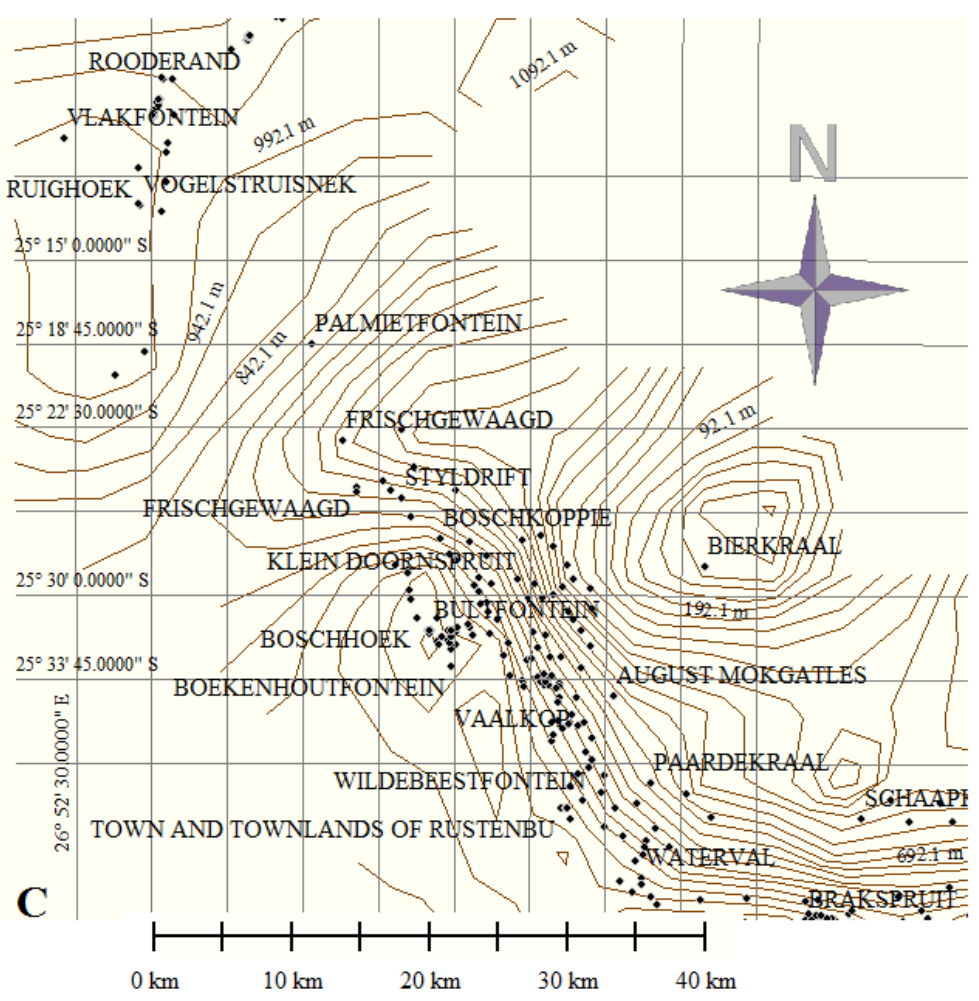




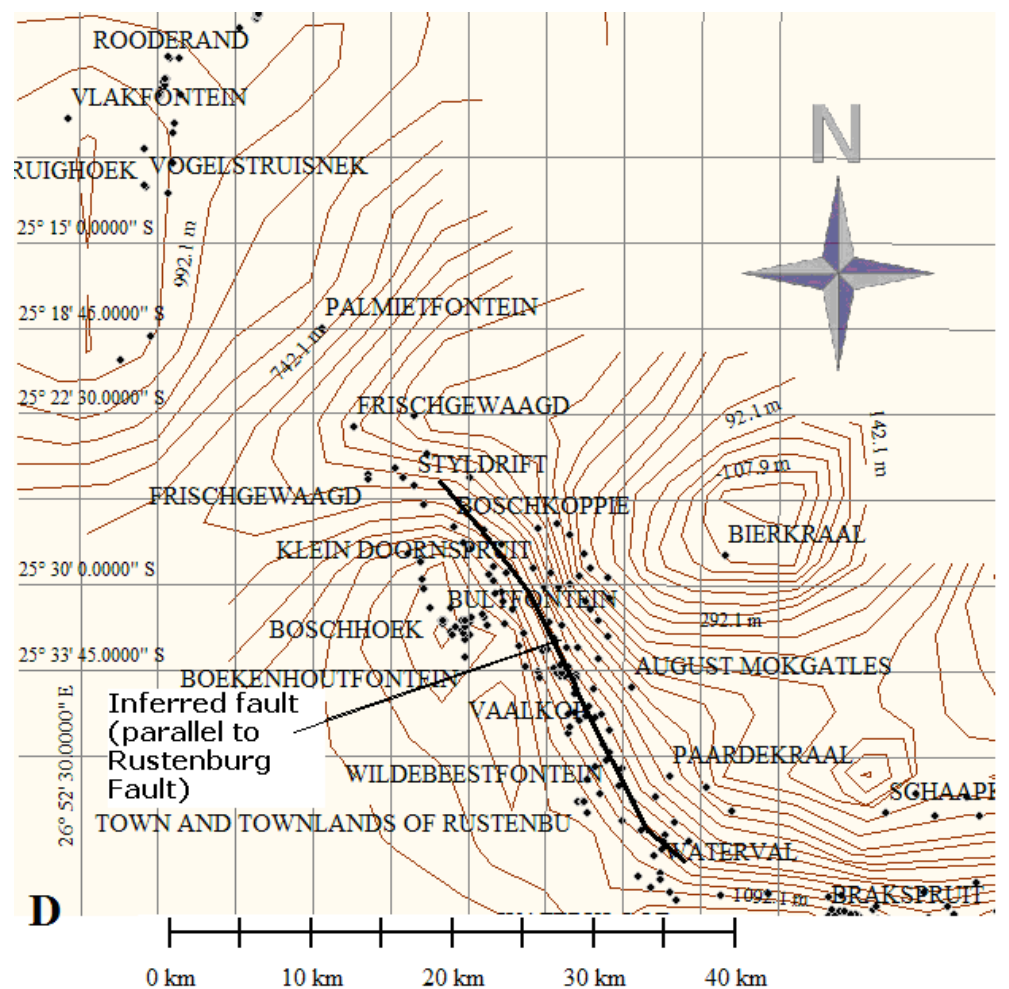

Figure 9A. Third and fourth order Main Zone residual structure of central parts of the Western Bushveld Complex (contour interval 50)

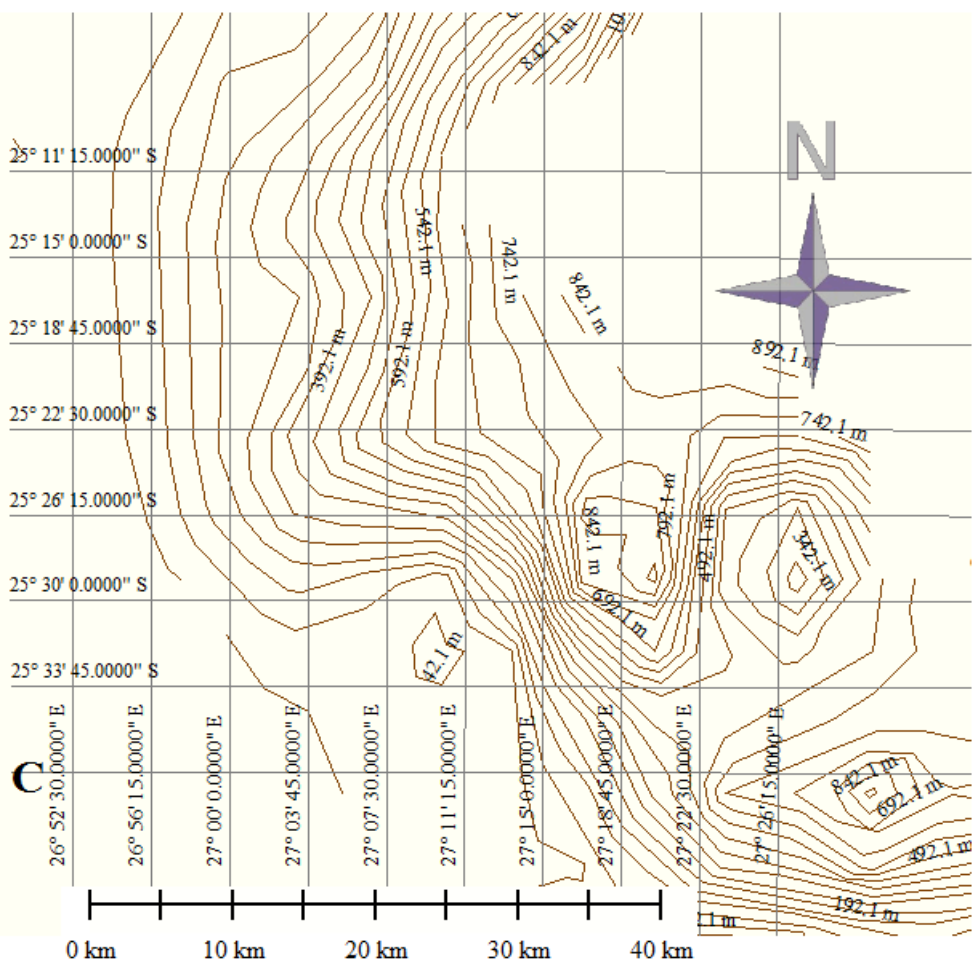




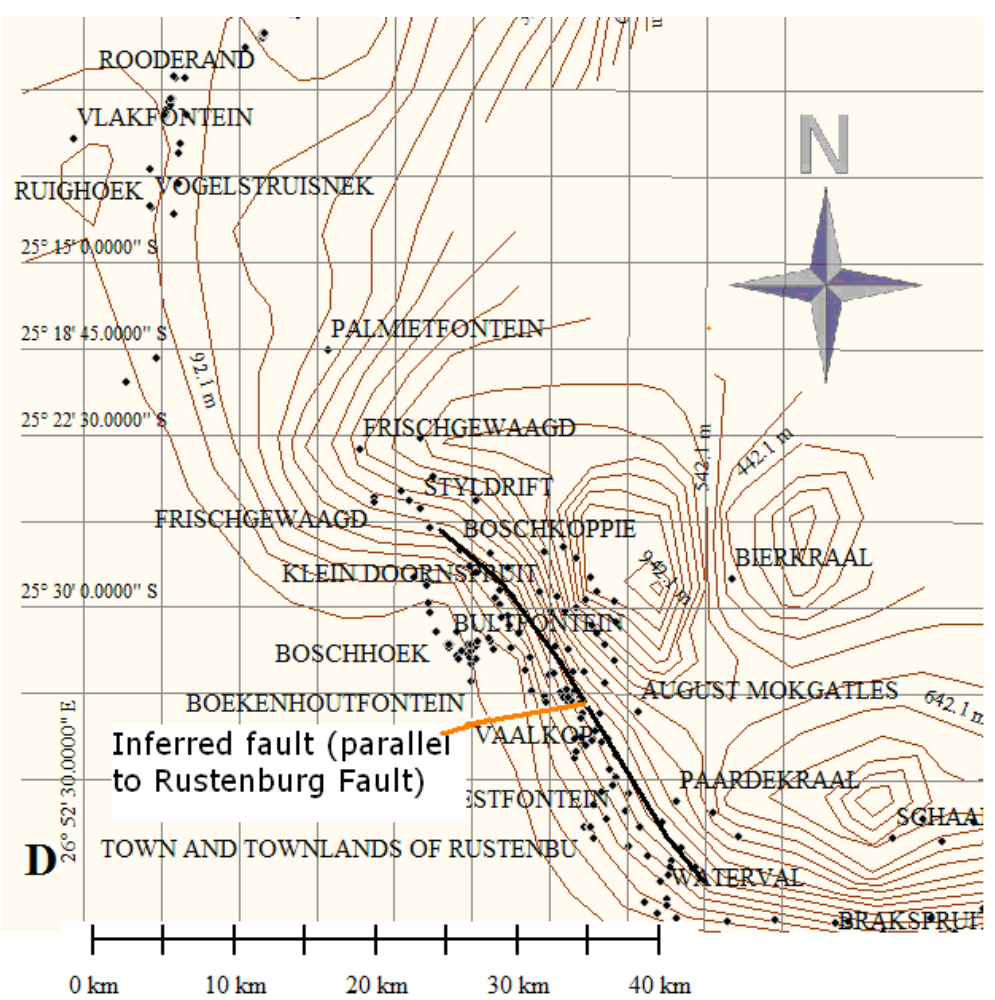

Figure 9B. Third and fourth order Main Zone isopach map of central parts of the Western Bushveld Complex (contour interval 50)

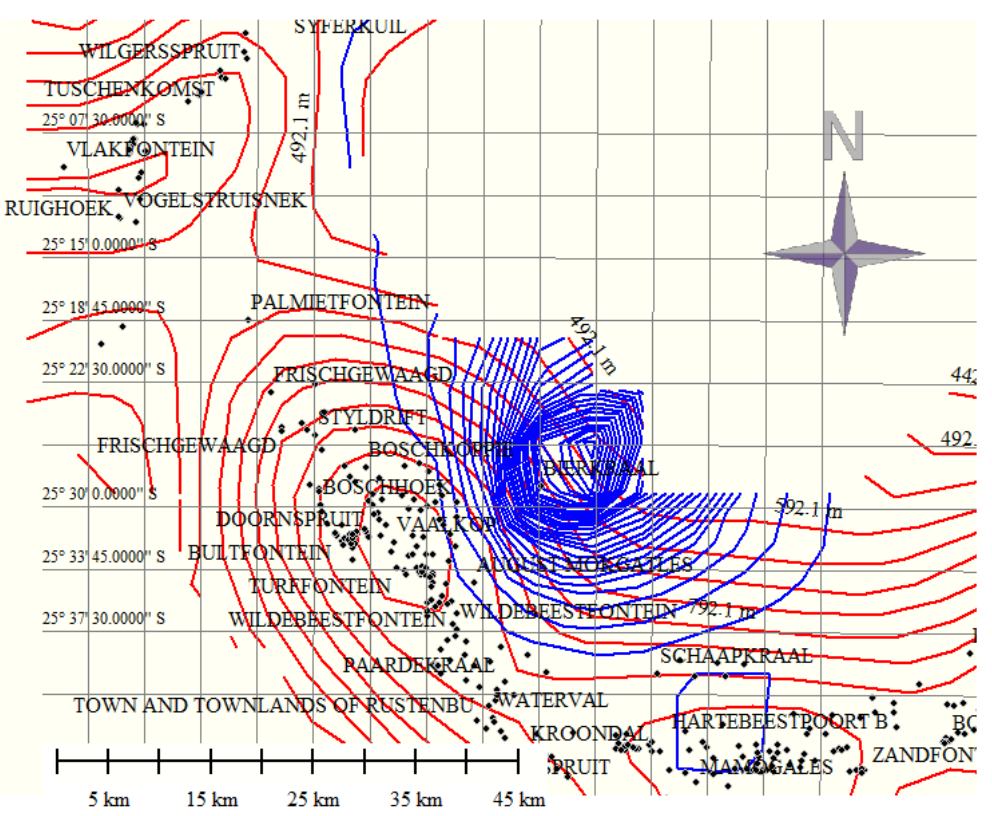

Figure 10. Upper Zone residual structure (red) of central parts of the Western Bushveld Complex overlain with Upper Zone residual isopach (blue) of the same area 


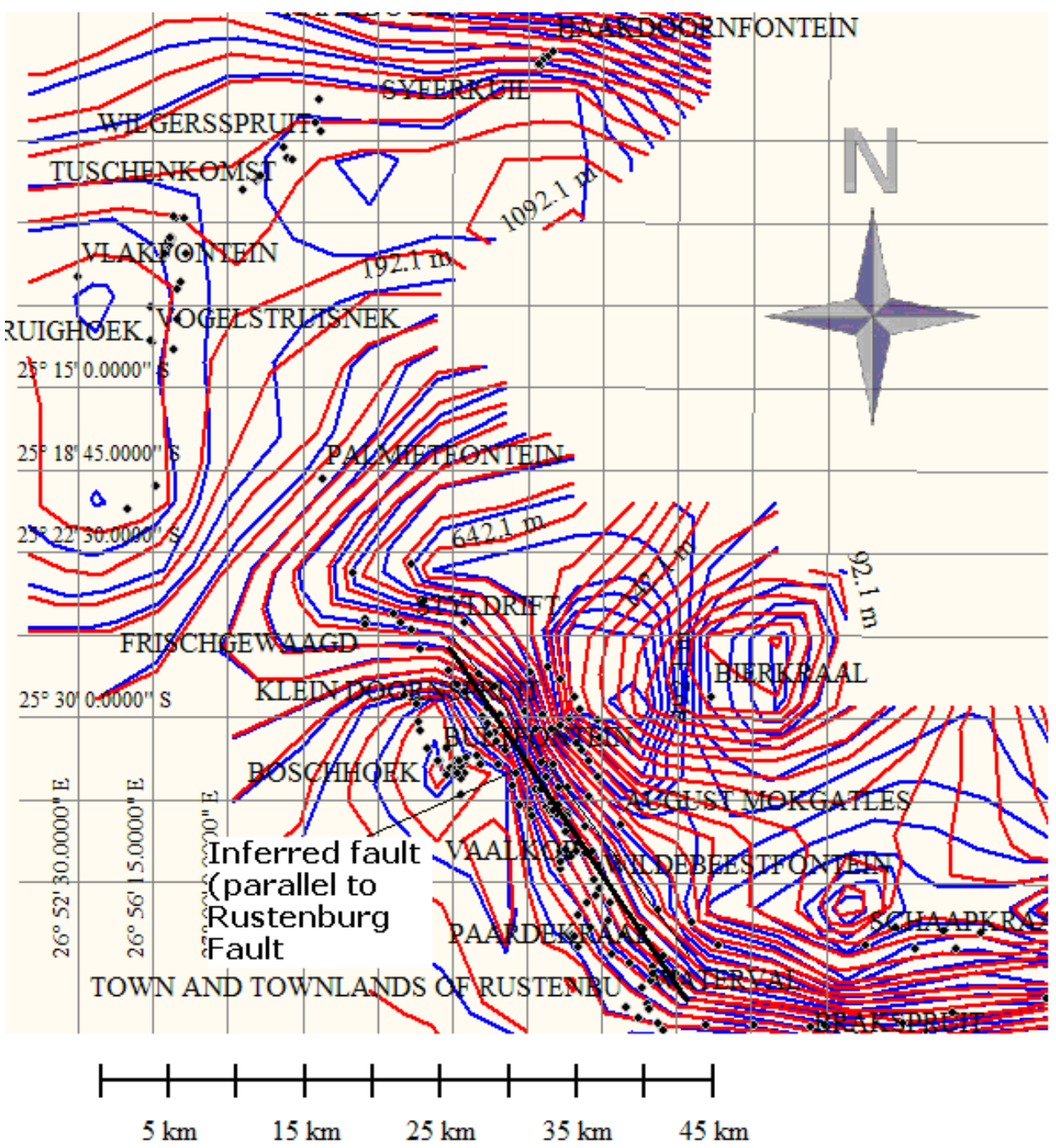

Figure 11. Main Zone residual structure (red) of central parts of the Western Bushveld Complex overlain with Main Zone residual isopach (blue) of the same area

\subsection{Relationship Between Residual Structure Contour and Isopach Maps of the Southwestern Bushveld}

The Main Zone and Upper Zone residual structure contour map in the northern part of the Southwestern Bushveld Complex consist of isolated structural negative areas. The western isolated negative structure (see Figure 12 and 13) forms an anticlinal shape and opens to the north. The eastern isolated negative structures occur on the northeastern side and open to the north in Figure 13. Most of the structural negative areas correspond directly to positive thickness areas.

The Brits Graben Faults are NNW trending in the Southwestern Bushveld (Bumby, Eriksson \& Van der Merwe, 1998) as revealed on the structure contour map. There is an inverse correlation between the structural elevation and thickness in this area (Figures 12 and 13): positive structural trends are associated with negative thickness trends. A strongly negative structural domain coincides with graben areas, while a strongly positive structural domain coincides with horst area. The central part of the Western Bushveld i.e. south of the Pilanesberg Complex also shows inverse correlation between structure and thickness. The trend of the Brits Graben coincides with the regional structural trend within the Kaapvaal Craton and thus signifies that the structures were probably formed in early Transvaal times and were reactivated during the intrusion of the Bushveld Complex (Hartzer,1989).

The trend pattern the Main Zone and Upper Zone structural map shows that the prominent trend is NE with northwest dip. This coincides with the outcrop trend in the area. 

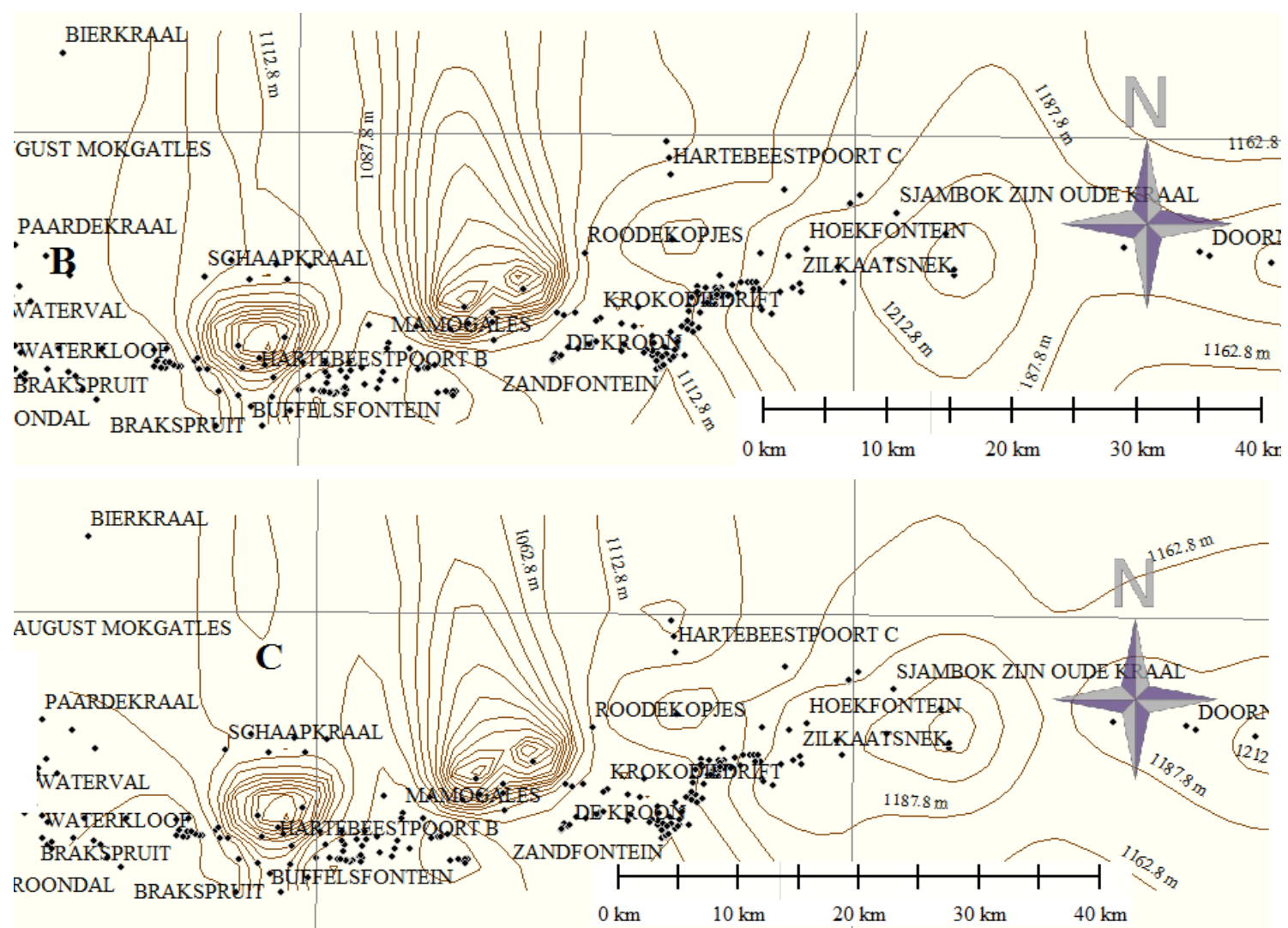

Figure 12. Upper Zone top interval residual structure ( B and C represent second and third orders respectively)
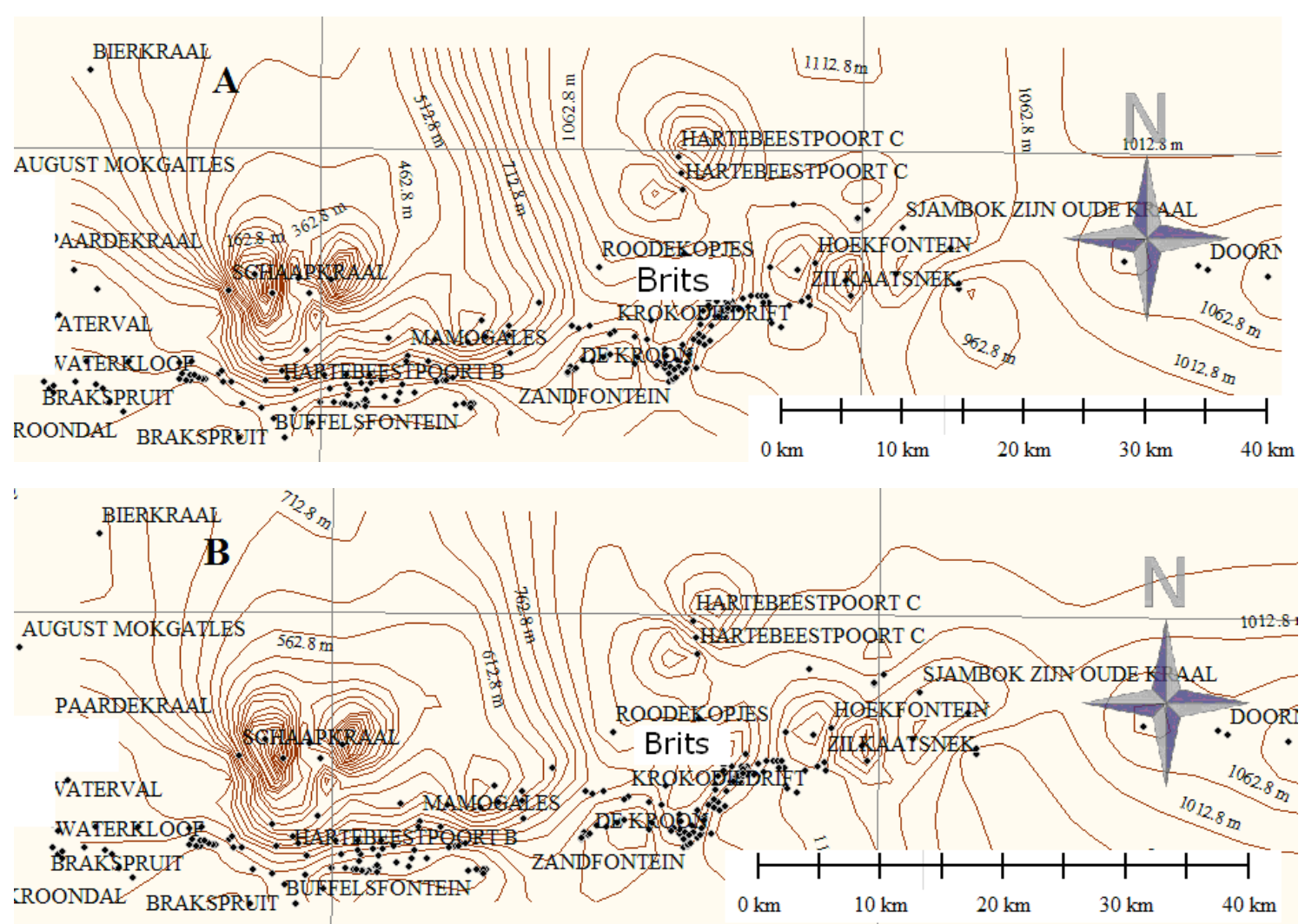

Figure 13. First and second order Upper Zone residual isopach. (A is first order, B is second order, C is third order and $\mathrm{D}$ is fourth order) 


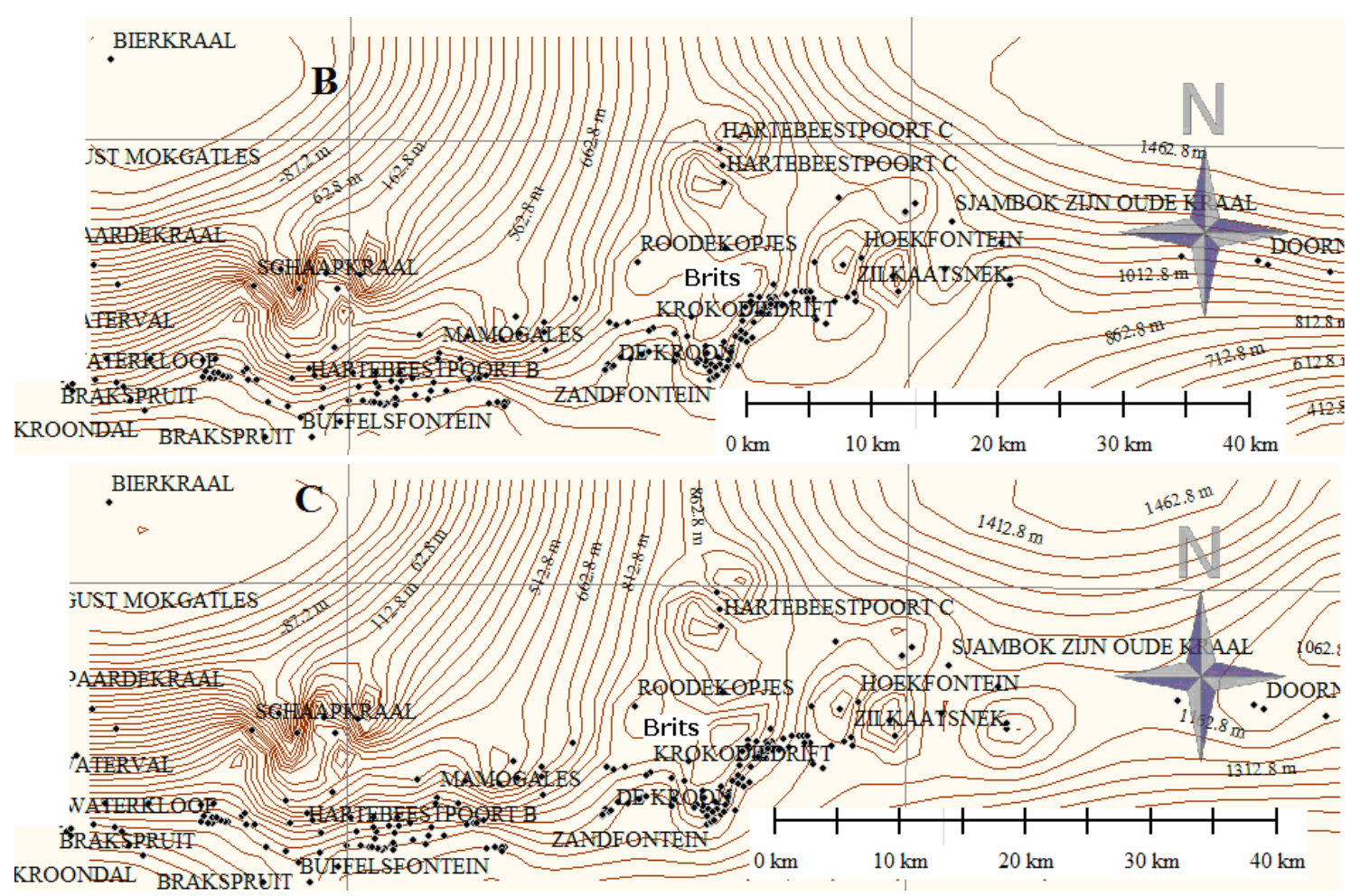

Figure 14. Main Zone second order (B) and third order (C) isopach trend of Southwestern the Bushveld Complex

\section{Discussion and Conclusion}

Most of the isopach maps in some parts of the RLS show thickening and thinning trends that coincides strongly with variation in structural grain on the geologic maps. Areas with positive thickening coincide with negative structural residual (structural lows, sags, troughs or synclines) areas. While positive structural residuals such as structural highs or anticline correspond to negative thickness residual domain. The Amandelbult section of the Northwestern Bushveld shows a relatively flat top masking a terrain of buried graben.

a. Inverse relationship between structure elevation and thickness was used to discriminate between pre and syn- Bushveld structures and relate the time sequence pattern of each stratigraphic unit. Most part of the Western Bushveld indicates inverse structure and thickness relationship. This inverse relationship indicate that most of the present day structures are intensifications of structures in place before the RLS were emplaced and only slight modification has occurred since their emplacement. These findings correspond to the results of field mapping conducted around the Rustenburg Fault by Bumby et al. (1998); Coertze (1962); (1970); (1974). Seismic refraction survey by Campbell (2009) also shows the presence of graben structures above floor anticlines (Trickett, Duweke \& Kock, 2004) in this area. Eales and Cawthorn (1996) also emphasized floor rock control on the RLS.

b. The use of 3D path profile with trend surface interpolation methods for structural analysis has facilitated the detection of regional features and their subsurface geometry.

c. The northern and southern gaps of the Northwestern Bushveld are associated with a NW-SE trending fault to the west and east of the gap area. The fault shows up as close contours on the structure contour for Main Zone base and successive stratigraphic zone structure maps.

d. Two distinct structural domains were identified based on difference in structural features observed, the overlying stratigraphic zones down to the top of the Main Zone differs from the underlying stratigraphic zones. Structures at the surface from the overburden to the base of the Upper Zone are very similar and differ from structural features at the base of the Main Zone through the Critical Zone to the Lower Zone. However, the Brits Graben area shows an inverse correlation between structure and thickness on all the stratigtraphic units indicating that Brits Graben is probably Pre or syn Transvaal.

e. Formation of most of the structures such as normal fault slumping and layer parallel slip movement has been attributed to structural readjustment of the underlying Transvaal Supergroup rocks (Smith \& Bassion, 
2006; Eriksson \& Reczko, 1995; Carr \& Groves, 1994). Others are said to be syn-magmatic due to density contrast, intrusion of syn- veins and pegmatites, slumping (Scoon \& Mitchell, 1994; Viljoen and Scoon, 1985; Lee, 1981; Viljoen, 1999, Wilson, Cawthorn, Kruger \& Grundvig., 1994; Ballhaus, 1988; Reid and Basson, 2002). These irregular structures might account for the formation of potholes in the area.

This study provides a synoptic view of the western lobe of the Bushveld Complex, allowing continuous trace of widely distributed terrain features and defines the geometry of the whole of the RLS in the area. It also gives details of the geometry of contact zones revealing the subsurface structural features and emplacement models, which are essential for future mineral exploration. Identification of thickening trends of each unit of the RLS proves to be significant for future exploration.

In conclusion, the study has significantly contributed to the knowledge about the regional and small-scale structural features within the study area. It also shows a new way of mapping structures in more detail.

\section{Acknowledgments}

The authors gratefully acknowledge the support of the Council for Geosciences, Pretoria for data and software provision, and the University of Pretoria for financial support.

\section{References}

Agterberg, F. P. (1984). Trend surface analysis. Spatial statistics and models. Springer. http://dx.doi.org/10.1007/978-94-017-3048-8_8

Baird, A., Baird, K., \& Morton D. (1971). On deciding whether trend surfaces of progressively higher order are meaningful: Discussion. Geological Society of America Bulletin, 82, 1219-1234. http://dx.doi.org/10.1130/0016-7606(1971)82[1219

Ballhaus, C. G. (1988). Potholes of the Merensky Reef at Brakspruit Shaft, Rustenburg platinum mines; primary disturbances in the magmatic stratigraphy. Economic Geology, 83, 1140-1158.

Barnes, S. J., \& Maier, W. D. (2002). Platinum-group element distributions in the Rustenberg Layered Suite of the Bushveld Complex, South Africa. . The Geology, Geochemistry, Mineralogy and Mineral Beneficiation of Platinum-Group Elements. Canadian Institute of Mining, Metallurgy and Petroleum.

Bumby, A, Eriksson P. G., \& Van Der, M. R. (1998). Compressive deformation in the floor rocks to the Bushveld Complex (South Africa): Evidence from the Rustenburg Fault Zone. Journal of African Earth Sciences, 27, 307-330. http://dx.doi.org/10.1016/s0899-5362(98)00065-7

Campbell, G. (1994). Geophysical contributions to mine-development planning: A risk reduction approach. In Proceedings XV CMMI Congress: SAIMM Symposium Series (pp. 283-325).

Campbell, G. (2006). High resolution aeromagnetic mapping of "loss-of-ground" features at platinum and coal mines in South Africa. South African Journal of Geology, 109, 439-458. http://dx.doi.org/10.2113/gssajg.109.4.439

Campbell, G. (2009). Seismic Reflection Surveys and structural mapping: Faults, dips and domes. 11th SAGA Biennial Technical Meeting and Exhibition. Swaziland.

Campbell, G. (2011). Exploration geophysics of the Bushveld Complex in South Africa. The Leading Edge, 30, 622-638.

Carr, H. W., \& Groves, D. I. (1994). The importance of synmagmatic deformation in the formation of Merensky Reef potholes in the Bushveld Complex. Economic Geology, 89, 1398-1410.

Cawthorn, R., Eales, H., Walraven F., Uken, R., \& Watkeys, M. (2006). The Bushveld Complex. The Geology of South Africa, 691, 261-281.

Cawthorn, R. G., \& Walraven, F. (1998). Emplacement and crystallization time for the Bushveld Complex. $J$. Petrol., 39, 1669-1687. http://dx.doi.org/10.1093/petroj/39.9.1669

Cawthorn, R. G., \& Webb, S. J. (2001). Connectivity between the western and eastern limbs of the Bushveld Complex. Tectonophysics, 330, 195-209. http://dx.doi.org/10.1016/s0040-1951(00)00227-4

Chunnett, G. K., \& Rompel, A. K. K. (2004). Data integration for structural interpretation in the Bushveld Complex. International Platinum Conference: 'PlatinumAdding Value'. The South African Institute of Mining and Metallurgy.

Coertze, F. (1962). The Rustenburg Fault as a controlling factor of ore-deposition South-West of Pilanesberg. Transactions Geological Society South Africa, 65, 253-262. 
Coertze, F. (1970). The geology of the western part of the Bushveld Igneous Complex. Geol. Soc. S. Afr. Spec. Publ, 1, 5-22.

Coertze, F. J. (1974). The geology of the basic portion of the Western Bushveld Igneous Complex, Geol. Surv. South Africa, Mem. 66, 148pp.

Cook, A. (1969). Trend-surface analysis of structure and thickness of Bulli Seam, Sydney Basin, New South Wales. Journal of the International Association for Mathematical Geology, 1, 53-78. http://dx.doi.org/10.1007/bf02047071

Davis, J. C. (1986). Statistical and data analysis in geology, J. Wiley.

Davis, J. C., \& Sampson, R. J. (2002). Statistics and data analysis in geology, Wiley New York.

Davis, R. W. (1973). Quality of Near - Surface Waters in Southern Illinois. Groundwater, 11, 11-18. http://dx.doi.org/10.1111/j.1745-6584.1973.tb02952.x A

Du Plessis, C. P., \& Walraven F. (1990). The Tectonic setting of the Bushveld Complex in Southern Africa, Part 1. Structural deformation and distribution. Tectonophysics, 179(3), 305-319. http://dx.doi.org/10.1016/0040-1951(90)90296-k

Eales, H., \& Cawthorn, R. (1996). The Bushveld Complex. Developments in Petrology, 15, 181-229.

Eriksson, P., Hattingh, P., \& Alterman, N. W. (1995). An overview of the geology of the Transvaal Sequence and Bushveld Complex, South Africa. Mineralium Deposita, 30, 98-111. http://dx.doi.org/10.1007/bf00189339

Evenick, J. (2008). Introduction to well logs and subsurface maps, PennWell Books.

Grohmann, C. H. (2005). Trend-surface analysis of morphometric parameters: a case study in southeastern Brazil. Computers \& geosciences, 31, 1007-1014. http://dx.doi.org/10.1016/j.cageo.2005.02.011

Hartzer, F. (1989). Stratigraphy, structure, and tectonic evolution of the Crocodile River Fragment. South African journal of geology, 92, 110-124.

Kinnaird, J. A. (2005). The Bushveld large igneous province. Review Paper, The University of the Witwatersrand, Johannesburg, South Africa, 39pp.

Krumbein, W. C. (1959). Trend surface analysis of contour-type maps with irregular control-point spacing. Journal of Geophysical Research, 64(7), 823-834. http://dx.doi.org/10.1029/JZ064i007p00823

Lee, C. (1981). Post-deposition structures in the Bushveld Complex mafic sequence. Journal of the Geological Society, 138, 327-341. http://dx.doi.org/10.1144/gsjgs.138.3.0

Odgers, A. T. R., Hinds, R. C., \& Von Gruenewaldt, G. (1993). Interpretation of a seismic reflection survey across the southern Bushveld Complex. South African journal of geology, 96(4), 205-212.

Odgers, A. T. R., \& Du Plessis, A. (1993, April). Interpretation of a regional reflection seismic survey in the north-eastern Bushveld Complex. In 3rd SAGA Biennial Conference and Exhibition.

Manyeruke, T. D. (2003). The petrography and geochemistry of the Platreef on the farm Townlands, near Potgietersrus, northern Bushveld Complex. University of Pretoria.

Mei, S. (2009). Geologist-controlled trends versus computer-controlled trends: introducing a high-resolution approach to subsurface structural mapping using well-log data, trend surface analysis, and geospatial analysis. Canadian Journal of Earth Sciences, 46, 309-329. http://dx.doi.org/10.1139/E09-006

Mei, S., \& Energy A. (2006). Structure Mapping for the Clear Hills-Smoky River Region Using Well-log Data and Geostatistical Analysis [electronic Resource], Alberta Energy and Utilities Board, Alberta Geological Survey.

Merriam, D. F., \& Harbaugh, J. W. (1964). Trend- surface analysis of regional and residual components of geologic structure in Kansas. State Geological Survey, University of Kansas.

Reid, D., \& Basson, I. (2002). Iron-rich ultramafic pegmatite replacement bodies within the Upper Critical Zone, Rustenburg Layered Suite, Northam Platinum Mine, South Africa. Mineralogical Magazine, 66, 895-914. http://dx.doi.org/10.1180/0026461026660066

Salvador, E. D., \& Riccomini, C. (1995). Neotecto^ nica de regia ${ }^{\wedge}$ do alto estrutural de Queluz. In: GrohmannC.H. Trend-surface analysis of morphometric parameters: A case study in southeastern Brazil. Revista Brasileira de Geociencias, 25, 151-164.

Scoon, R. N., \& Mitchell, A. A. (1994). Discordant iron-rich ultramafic pegmatites in the Bushveld Complex and 
their relationship to iron-rich intercumulus and residual liquids. Journal of Petrology, 35, 881-917. http://dx.doi.org/10.1093/petrology/35.4.881

Shaw, B. R. (1977). Evaluation of distortion of residuals in trend surface analysis by clustered data. Journal of the International Association for Mathematical Geology, 9, 507-517. http://dx.doi.org/10.1007/bf02100962

Smith, D. S., \& Basson, I. J. (2006). Shape and distribution analysis of Merensky Reef potholing, Northam Platinum Mine, western Bushveld Complex: implications for pothole formation and growth. Mineralium Deposita, 41, 281-295. http://dx.doi.org/10.1007/s00126-006-0059-5

S.A.C.S (1980). Stratigraphy of South Africa Part 1: Lithostratigraphy of the Republic of South Africa, South West Africa/Namibia and the Republics of Bophuthatswana, Transkei and Venda. Handbook Geological Survey South Africa. Pretoria, South Africa.

Trickett, J. C., Duweke, W., \& Kock, S. (2004). The three dimensional reflection seismic: worth its weight in platinum. SAIMM Journal of the South African Institute of Mining and Metallurgy, 105, 252-263.

Unwin, D. (2009). Trend Surface Models. Kitchin R, Thrift N. International Encyclopedia of Human Geography. Oxford: Elsevier, 11, 484-488.

Viljoen, M. (1999). The nature and origin of the Merensky Reef of the western Bushveld Complex based on geological facies and geological data. South African Journal of Geology, 102, 221-239.

Viljoen, M. J., \& Scoon, R. N. (1985). The distribution and main geologic features of discordant bodies of iron-rich ultramafic pegmatite in the Bushveld Complex. Economic Geology, 80, 1109-1128.

Von gruenewaldt, G., Hatton, C., \& Merkle, R. (1986). Platinum-group element-chromitite associations in the Bushveld Complex. Economic Geology, 81, 1067-1079. http://dx.doi.org/10.2113/gsecongeo.81.5.1067

Walraven, F., Armstrong, R. A., \& Kruger, F. J. (1990). A chronostratigraphic framework for the north central Kaapvaal craton the Bushveld Complex and the Vredefort Structure. Tectonophysics, 171, 23-48. http://dx.doi.org/10.1016/0040-1951(90)90088-p

Wharton, S. R. (1993). An Integrated Approach to the Study of Pliocene Gros Morne Reservoir Sands For Developing Play Concepts Society of Petroleum Engineers, 11th Technical Conference and Exhibition, June 23-25, 1993 Trinidad. Moruga East Field, Trinidad.

Wilson, J., Cawthorn, R., Kruger, F., \& Grundvig, S. (1994). Intrusive origin for the unconformable Upper Zone in the Northern Gap, western Bushveld Complex. S Afr J Geol, 97, 462-472.

Wren, A. (1973). Trend surface analysis-a review. Canadian Journal of Exploration Geophysics, 9, 39-44.

\section{Copyrights}

Copyright for this article is retained by the author(s), with first publication rights granted to the journal.

This is an open-access article distributed under the terms and conditions of the Creative Commons Attribution license (http://creativecommons.org/licenses/by/3.0/). 